V. Gnatyuk National Pedagogical University of Ternopil

(2, M. Kryvonos Str., Ternopil 46027, Ukraine; e-mail: korsun_igor@mail.ua)

The contribution of Ukrainian scientists to the development of quantum physics has been analyzed, and a classification in accordance with corresponding branches has been made. The importance of researches in this physical domain is demonstrated. The priority of Ukrainian scientists in a number of scientific issues in the world science is shown. Attention is paid not only to the scientific activity of physicists, but also to their pedagogical and educational works. The importance of current researches carried out by Ukrainian scientists is demonstrated.

Keywords: quantum physics, Ukrainian scientists, scientific activity, pedagogical work, educational work.

Ukraine was and remains to be a country with a high level of science development. As a proof of this statement, one may take the international recognition of achievements made by Ukrainian scientists. It is very important that those achievements should be known not only to a confined number of scientists, but also to the youth. Therefore, this information has to be included into higher-school courses of physics. The contribution of Ukrainian scientists to the development of physics was demonstrated in a lot of manuals [1-9], as well as scientific and methodological papers [10-13]. However, despite that, this issue remains challenging, because the achievements of Ukrainian scientists are substantial and demand a further analysis.

The domain of quantum physics was chosen, because a considerable number of researches are currently carried out in this direction. It is clear that all achievements of Ukrainian physicists in this scientific domain could not be covered in this paper, so that the contributions of plenty of other scientists remained beyond consideration. The aim of this work was to prove that, owing to the works of Ukrainian scientists, the world quantum physics both gained a strong impetus in the preceding years of its history and continues to develop further today.

(c) I.V. KORSUN, 2017

ISSN 2071-0194. Ukr. J. Phys. 2017. Vol. 62, No. 1

\section{Thermal Radiation}

Volodymyr Oleksandrovych Mikhelson. Born in 1860 in Tulchyn, died in 1929 in Moscow. Physicist, geophysicist, and meteorologist.

V.O. Mikhelson was the first who applied the methods of statistical physics to determine the distribution function of energy in the blackbody radiation spectrum [14]. Mikhelson's work "Experience of a theoretical explanation of energy distribution in the solid spectrum" (1887) was a first attempt to solve the problem concerning the form of Kirchhoff's function. It had pointed a way that led W. Wien to a more exact approximation and M. Planck to the ultimate solution of the problem.

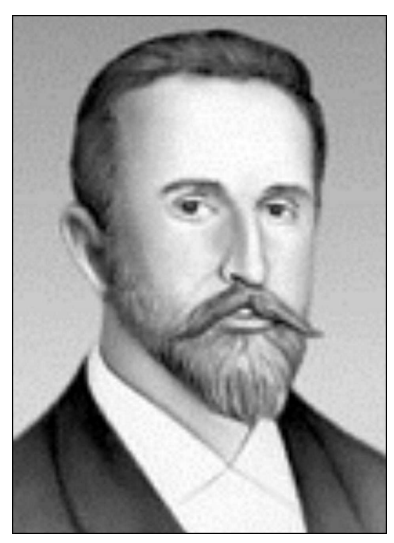

V.O. MIKHELSON 


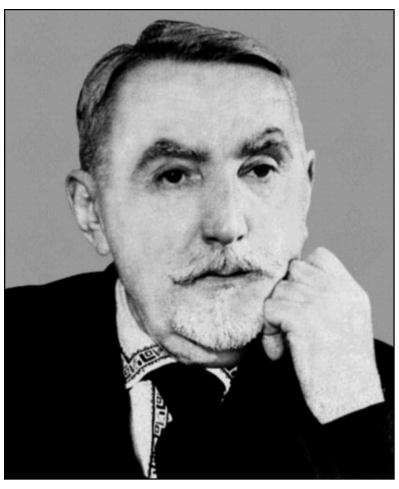

E.A. KIRILLOV

V. Mikhelson obtained an equation for Kirchhoff's function in the form

$\varepsilon_{\lambda, T}=C_{1} T^{\frac{3}{2}} \lambda^{-6} \exp \left(-\frac{C_{2}}{T \lambda^{2}}\right)$,

where $C_{1}$ and $C_{2}$ are constants.

The curves calculated from this equation reproduced the general behavior of experimental curves, but they had a steeper recession slope.

The expression for $\lambda_{\max }$ can be obtained from Mikhelson's equation (1) by equating the derivative $d \varepsilon_{\lambda, T} / d \lambda$ to zero:

$\lambda_{\max }^{2} T=$ const.

Hence, Mikhelson rather closely approached Wien's shift law

$\lambda_{\max } T=$ const.

In 1896, W. Wien, proceeding from Mikhelson's works, obtained an expression for Kirchhoff's function. This expression described the experiment more precisely than Mikhelson's formula (1) did. Wien's formula looks like

$\varepsilon_{\lambda, T}=C_{1} \lambda^{-5} \exp \left(-\frac{C_{2}}{\lambda T}\right)$.

It is not obeyed at large values of the quantity $\lambda T$ corresponding to large wavelengths and high absolute temperatures.

Therefore, M. Planck made Wien's formula (4) more complicated:

$\varepsilon_{\lambda, T}=C_{1} \lambda^{-5} \frac{1}{\exp \left(\frac{C_{2}}{\lambda T}\right)-1}$.

Formula (5) obtained by Planck describes all experimental data.

68
Later, Mikhelson returned back to the theory of thermal radiation in his works "Essays on spectral analysis" (1901) and "Review of the newest researches in the thermodynamics of radiant energy" (1902).

\section{Quantum Optics}

Elpidifor Anempodystovych Kirillov. Born in 1883 in the village of Shypka (Moldova), died in 1964 in Odesa. Founder of the Odesa scientific school in scientific photography, discoverer of negative photoeffect.

In 1924, E. Kirillov began regular researches of the phenomena that play an important role at the fabrication of photographic materials [15]. In view of the large importance of those researches, the scientist was appointed the director of the Scientific and Research Institute of Physics (he had been holding this position for about 40 years). The institute became a leading center of the physics of silver halogenides. As a recognition of success achieved by Odesa physicists, Odesa became the place of the first All-Union congress of physicists (1930) and the first All-Union conference on semiconductor physics (1934).

In 1930, E. Kirillov discovered the phenomenon of negative photoeffect (the photoeffect created by light with one frequency is "neutralized" by light with another frequency). He researched this phenomenon and showed that it is associated with the process of latent photographic image formation. Therefore, a relation between photoelectric and photochemical processes was revealed.

Since 1921, E. Kirillov had been heading the Chair of experimental physics at the Odesa State University (now, I.I. Mechnikov National University of Odesa). More than 50 years of his creative life were devoted by the scientist to the work at the university. In 19441950, Kirillov also headed the Chair of physics at the Odesa Medical University (now, the Odesa National Medical University). As the head of the chair, he paid much attention to the content of the educational programs for students and to the lecturing methodology. The scientist carefully prepared for his lectures (in particular, he came an hour before the lecture began and checked an equipment), created educational laboratories, and monitored the state of their equipment [16].

Ostap Oleksandrovych Stasiw. Born in 1903 in the village of Borshchovychi (the Lviv region), died in

ISSN 2071-0194. Ukr. J. Phys. 2017. Vol. 62, No. 1 
1985 in Alfeld (Germany). Ukrainian physicist, Director of the Institute of Crystal Physics in Berlin, one of the founders of the international journal Physica Status Solidi.

In 1937-1945, O. Stasiw worked as the head of a laboratory at the "Zeiss Icon" firm in Dresden. At that time, there emerged a problem concerning the enhancement of the photographic film sensitivity. That was the problem that the Ukrainian physicist worked at. The theory of latent photographic image formation, which was put forward by N. Mott and R. Gurney in 1938, obtained a wide recognition at that time. However, some aspects of this theory (the structure of capture centers, the types of charge carriers and the mechanisms of their localization, and possible ways to enhance the sensitivity of photographic materials) remained obscure. The corresponding researches were carried out by O. Stasiw and J. Teltow [17].

A cycle of important researches was started in 1939. Those works [18-20] laid a basis for the development of the concept dealing with the structure of the centers of latent photographic image and the mechanisms of image formation. The scientists demonstrated the double role of impurities, the formation of complex (colloidal) defects, the role of photolysis phenomena, and the role of hole-type carriers in the formation of latent photographic image centers in sulfur-sensitized photoemulsions. Hence, the Stasiw-Teltow model essentially developed and specified the Mott-Gurney scenario, which had a considerable value for the perfection of the technology of photographic materials.

Vadym Evgenovych Lashkaryov. Born in 1903 in Kyiv, died in 1974 in Kyiv. Ukrainian scientist, Academician of the Academy of Sciences of the UkrSSR, founder of the first scientific school of semiconductor physics in Ukraine.

After graduating from the Kyiv Institute of National Education (1924), V.E. Lashkaryov studied there as a postgraduate student (1924-1927) and simultaneously worked as a teacher [21]. At that time, his researches concerned X-radiation and the development of a corresponding equipment [22]. In 1925, together with V.P. Linnyk, V.E. Lashkaryov developed an original method for the determination of the refractive index for X-radiation [23].

Later, working at the Leningrad Physico-Technical Institute (1930-1935), V.E. Lashkaryov studied the

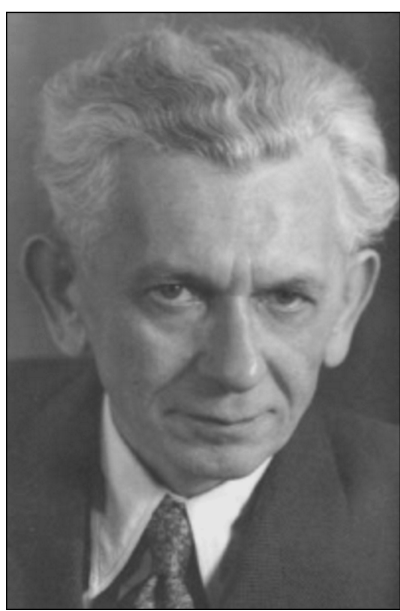

O.O. STASIW

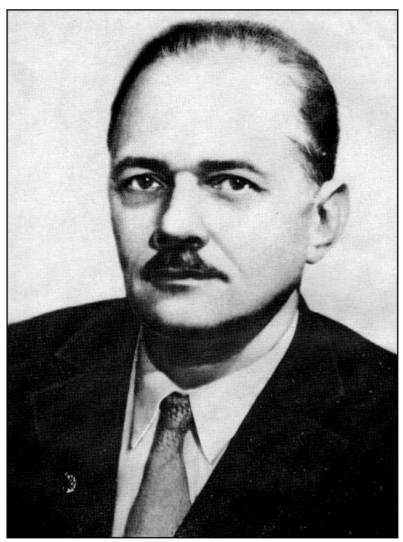

V.E. LASHKARYOV

diffraction of low- and high-energy electrons (he was the Head of the electron diffraction laboratory). The results of those researches were published in the monograph "Electron Diffraction" (1933). The scientist was conferred the scientific degree of Dr. Sci. in physics and mathematics without defending the thesis.

Since 1939, Lashkaryov had been the Head of the Department of semiconductors at the Institute of Physics of the AS of the UkrSSR. He experimentally discovered the $p-n$ transition in cuprous oxide (1941). In 1948, he developed a general theory describing the emergence of a photoelectromotive force in semiconductors [24] and discovered the bulk photo-emf.

The scientist paid a large attention to the training of the scientific staff. Since 1944, he had been the 


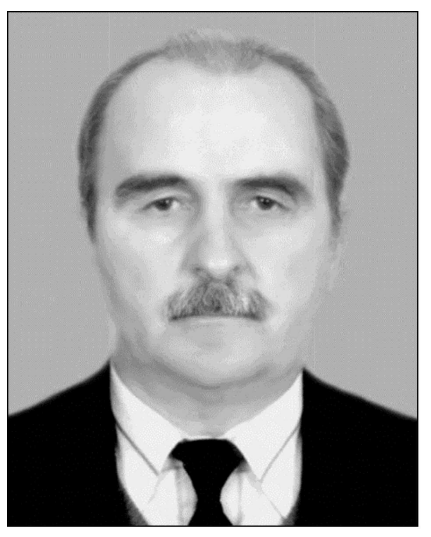

A.P. GORBAN'

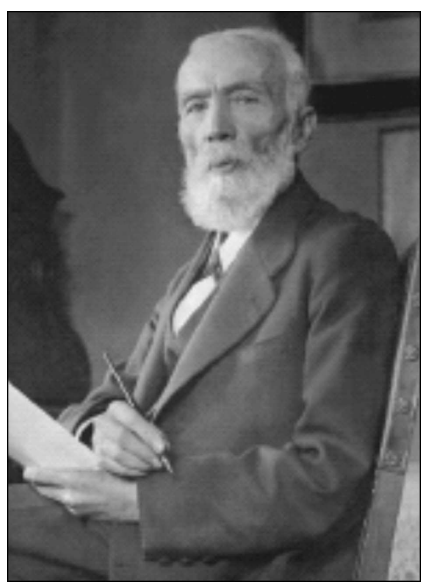

I.P. PULYUI

Head of the Chair of physics at the Kyiv State University. At the university, he created the educational speciality "Semiconductor physics". Later, he founded the Chair of semiconductors there (the first in the Soviet Union) and was its head till 1956.

V.E. Lashkaryov was a founder and the Editorin-Chief (1956-1970) of the Ukrainian Journal of Physics. He was a winner of the State Prize of the UkrSSR (1981, posthumously). The Institute of Semiconductor Physics of the NAS of Ukraine was named after him in 2002.

Anatolii Petrovych Gorban'. Born in 1938 in Kyiv, died in 2009 in Kyiv. Ukrainian physicist, Chief designer of photo batteries for feeding the first Ukrainian space vehicles.

In 1996, the National space agency of Ukraine appointed A.P. Gorban' the Chief designer of photo- electric batteries for space vehicles of the Microsatellite type [25]. The same year, a scientific and research department of physical and technological bases of semiconductor photoenergetics was created at the Institute of Semiconductor Physics of the NAS of Ukraine. The department was included into the "Surface science and microelectronics" branch of the NAS of Ukraine. A.P. Gorban' became the Head of this department.

A.P. Gorban' was a winner of the State Prize of Ukraine in science and engineering in 2007. He published more than 200 scientific works, including a monograph. He had more than 20 author's certificates and patents for inventions [26].

\section{Atomic Physics}

Ivan Pavlovych Pulyui. Born in 1845 in Grymailiv (the Ternopil region), died in 1918 in Prague. Ukrainian physicist, electrical engineer, inventor.

The "Pulyui lamp" is a prototype of modern X-ray devices. The Technical museum in Prague has a working specimen of the Pulyui lamp [27]. With the help of this device, I. Pulyui made an X-ray image, which was the first in the world practice. At the International Electrotechnical Exhibition in Paris (1881), Pulyui's device was awarded the silver medal. W. Röntgen's researches - W. Röntgen is the Nobel Laureate in physics (1901) for the discovery of X-radiation are related to 1895 . Röntgen did not specify what tube was used, when unknown radiation was revealed. Immediately after Röntgen's report about the discovery of X-rays (1896), I. Pulyui published his works, where he - one of the first in science - called X-radiation as Röntgen rays [28].

Mykola Dmytrovych Pylchykov. Born in 1857 in Poltava, died in 1908 in Kharkiv. Ukrainian physicist, inventor, Professor of the Kharkiv and Odesa Universities and the Kharkiv Institute of Technology.

When working at the Odesa university (18941902), M. Pylchykov improved the "Pulyui lamp" by applying a concave anticathode. In science, this device was called the "Pylchykov focus-tube". The scientist was actively engaged in the tutorial work; he gave public lectures. W. Röntgen is known to have sent a letter of thanks to Pylchykov [29].

In 1899-1900, the scientist carried out the experimental researches of radioactivity first in Ukraine [30, 31]. M. Pylchykov studied the origin of X-radiation

ISSN 2071-0194. Ukr. J. Phys. 2017. Vol. 62, No. 1 
and its dependence on various physical factors. He researched the natural radioactivity of radium and thorium salts, and demonstrated their ionization, fluorescent, and photographic properties [32].

M. Pylchykov was an author of about 100 works, more than 25 original devices and installations, and some new experimental research methods. Before his death, the scientist bequeathed all his money to award technology students for the best diploma theses.

Leonid Yosyfovych Kordysh. Born in 1878 in Kyiv, died in 1932 in Kyiv. Ukrainian physicist, Dr. Sci. in physics and mathematics, professor, Corresponding Member of the All-Ukrainian academy of Sciences (1926), Member of the Krakow Academy of Sciences (1926).

After graduating from the St. Volodymyr University (now, the Kyiv National University), L.Yo. Kordysh was missioned to Berlin (1904), where he worked under the supervision of M. Planck [33]. In 1911-1912, he made a scientific trip to the Sorbonne University (Paris). There, he studied secondary oscillations and worked under the supervision of Henri Poincaré. L.Yo. Kordysh substantiated an original theory of secondary oscillations, extended this theory to include electromagnetic oscillations, and predicted the existence of mixed light oscillations [34]. In his work "Band spectra", he expressed the opinion that the band spectra are generated by molecules, whereas the linear ones by atoms. L.Yo. Kordysh gave an original explanation for the light dispersion phenomenon (in his work "White light dispersion").

In 1913, L.Yo. Kordysh had a scientific internship in Germany: at A. Sommerfeld and at the laboratory of electric oscillations of the Polytechnical Institute in Munich, where he developed a general theory of the Zeeman effect. After returning to Kyiv (1916), he initiated researches in atomic spectroscopy in Ukraine. L.Yo. Kordysh defended his thesis for the doctoral degree "Anomalous Zeeman phenomenon" in 1916. In 1921, he was elected the Professor of theoretical physics at the Kyiv University and headed the Chair of theoretical physics (1922-1932). When developing the theory of the Zeeman effect, L.Yo. Kordysh was the first who put the idea about a spatial arrangement of electron orbits in an atom in its basis [35, p. 5]. In order to explain the anomalous phenomenon, the scientist proposed a concept, according to which the electron motion in the field is

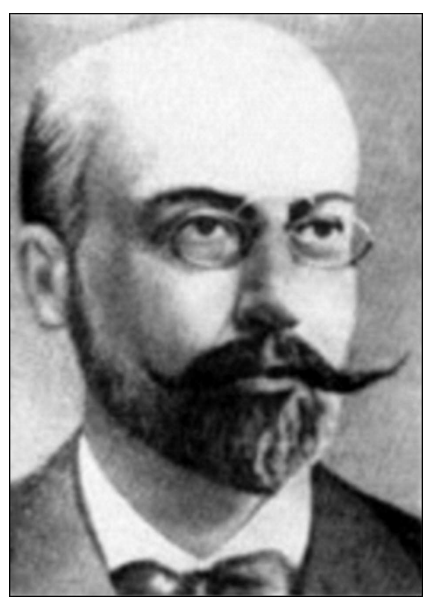

M.D. PYLCHYKOV

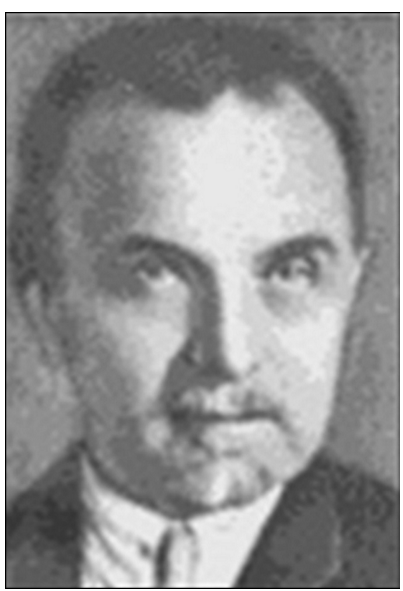

L.YO. KORDYSH

affected not only by the external field, but also by the internal field generated by the motion of other electrons. He obtained an equation that predicted the precession and mutation in the electron motion under the combined action of the magnetic field and the central force. In 1924, L.Yo. Kordysh determined the polarization of the components which the special line splits into in a magnetic field. However, false assumptions about the number of electrons in the atom and attempts to find the magnitude of internal magnetic field, which were based on them, prevented L.Yo. Kordysh from the creation of a complete theory of the anomalous Zeeman effect [35].

L.Yo. Kordysh worked at the theory of X-radiation ("On the wave nature of X-rays", "Coolidge X-ray tubes", "Residual X-rays", 'On the origin of charac- 


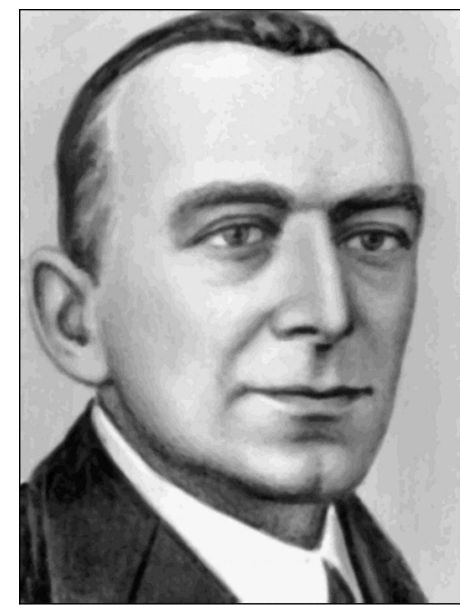

O.I. BRODS'KYI

teristic X-rays"). In 1923, he presented the theory of continuous X-radiation spectrum and derived a relation between the wavelength of the most intense radiation and the value of potential.

Almost the entire pedagogical activity of the scientist took place in his native Kyiv (he was the Professor of the Kyiv University and the Kyiv Polytechnic Institute). He was invited to the Kyiv X-ray Institute to organize and head an X-ray physical laboratory; he organized an Ukrmet laboratory dealing with the research of radioactive properties of soils and rocks in Ukraine, a laboratory of radio engineering at the Kyiv Polytechnic Institute, physical laboratories at the Crimean University, the Higher female courses institute, and the Female medical institute. When working at the Scientific and research institute of physics (he was the Head of the theoretical department of this institute), L.Yo. Kordysh was involved in the training of post-graduate students.

The importance of researches carried out by L.Yo. Kordysh was mentioned by L.Ya. Shturm: "The scientific activity of L.Yo. Kordysh in Ukraine had an especially important role. Here, he had been the almost sole representative of theoretical physics. One could say that, for many years, he "planted" this branch of science in Ukraine, invoking interest to its fundamental problems" [34, p. 972].

\section{Nuclear Physics}

Oleksandr Illich Brods'kyi. Born in 1895 in Ekaterynoslav, died in 1969 in Kyiv. Ukrainian scientist in physical chemistry, Dr. Sci in chemistry
(1926), Professor (1934), Academician of the AS of the UkrSSR (1939), Corresponding Member of the AS of the USSR (1943), Honored worker in science of the UkrSSR (1965), Honorary member of the Polish Academy of Sciences (1963), Director of the Institute of Physical Chemistry of the AS of the UkrSSR (1939-1969).

Under the supervision of O.I. Brods'kyi, the installation first in the USSR for the heavy water production was fabricated (1934, at the Institute of Physical Chemistry of the AS of the UkrSSR), as well as installations for producing the concentrates of heavy oxygen (1937) and heavy nitrogen (1949). Heavy water was used in early nuclear power experiments [36].

The scientist developed a general theory of isotope separation and methods of isotope analysis [37]. O. Brods'kyi was the first who applied stable isotopes to study the mechanisms of chemical reactions. He found that, by monitoring the isotope composition of water, it is possible to watch the drift of Arctic ice floes. In cooperation with the Institute of Geological Sciences of the AS of the UkrSSR, he obtained data about the geological composition of rocks and minerals and created a geochronological map of Ukraine, which facilitated the search of mineral deposits.

O. Brods'kyi is the author of more than 300 scientific works devoted to the theory of electrolyte solutions, chemistry of isotopes, research of chemical reaction mechanisms. He was a member of editorial boards of the "Journal of Physical Chemistry" and "Reports of the AS of the UkrSSR". His work "Chemistry of Isotopes" (1952) was the first monograph on this topic in the world science.

Dmytro Dmytrovych Iwanenko. Born in 1904 in Poltava, died in 1994 in Moscow. The author of the proton-neutron model of atomic nuclei.

After finishing the Poltava gymnasium in 1920, D. Iwanenko worked as a teacher of physics at the Labor school in Poltava. Simultaneously, the future scientist studied at the Poltava Pedagogical Institute (1920-1923) and worked at the Poltava astronomical observatory. Afterward, he studied at the Kharkiv and Leningrad Universities (1923-1927), worked at the State Physico-Technical Institute (Leningrad, 1927-1929), was the Head of the department of theoretical physics at the Ukrainian Physico-Technical Institute (Kharkiv, 1929-1931), the Head of the department at the Leningrad Physico-Technical Institute 
(1931-1935), and the Head of the Chair of physics at the Leningrad Pedagogical Institute (1933-1935).

In 1932, D. Iwanenko proposed the proton-neutron model for a nucleus [38]. Later, this theory was developed by W. Heisenberg. A lot of his scientific works, D. Iwanenko executed together with known physicists. For example, together with G. Gamow, he derived the Schrödinger equation (1926) proceeding from the model for the 5-dimensional space [39]; together with S. Ambartsumian, he put forward a hypothesis about the creation of massive particles in the course of interaction (1930), which formed the basis for the quantum field theory [40]; together with the Professor of the Kharkiv Medical Institute E. Gapon, he developed the shell model for atomic nuclei (1932) [41]; together with I. Tamm, he showed that the interaction by exchanging particles with nonzero rest mass is possible (1934), which laid the fundamentals of the nuclear force theory [42]; and together with A. Sokolov, he developed the mathematical apparatus of the theory of cosmic-ray showers (1938) [43].

When working at the Ukrainian Physico-Technical Institute (Kharkiv, 1932), the scientist became one of the founders and the editor of the physical journal "Physikalische Zeitschrift der Sowjetunion" published in foreign languages. D. Iwanenko was an initiator and a scientific secretary of the 1st All-Union Nuclear Conference (Leningrad, 1933). After defending his doctoral thesis "Fundamentals of nuclear force theory" (1940), the scientist headed the Chair of theoretical physics at the Kyiv University.

D. Iwanenko was an author of more than 300 scientific works, 4 monographs, and an editor of 27 books and collections of works.

Anton Karlovych Valter. Born in 1905 in Petersburg, died in 1965 in Kharkiv. Academician of the AS of the UkrSSR.

His scientific works are devoted to the physics of insulators and semiconductors, high-voltage engineering, physics of atomic nucleus and high energies, physics and technology of vacuum, and accelerating equipment. In 1932, A.K. Valter together with A.I. Leipunskyi, K.D. Sinel'nikov, and G.D. Latyshev, for the first time in the USSR, split the lithium nucleus using artificially accelerated protons. He supervised the creation of a few charged-particle accelerators, including a $2-\mathrm{GeV}$ linear electron accelerator.

In 1930, A.K. Valter was assigned to Kharkiv to organize work at the Ukrainian Physico-Technical

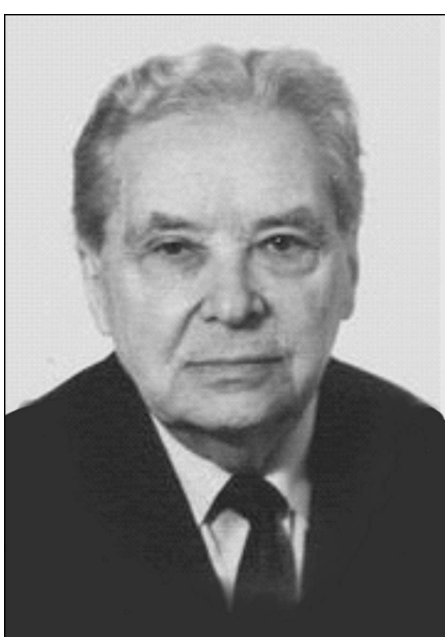

D.D. IWANENKO

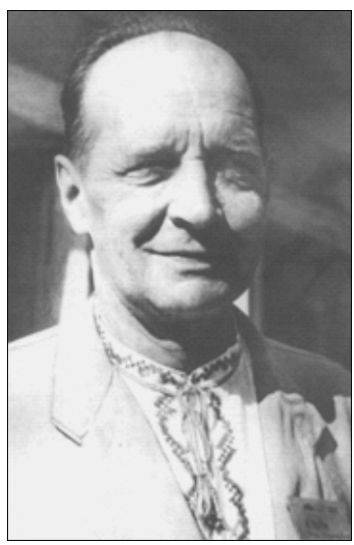

A.K. VALTER

Institute. He was among the founders of the Chair of atomic nucleus at the Kharkiv State University, which he had been heading since the moment of its foundation (1937-1965). He was a supervisor of more than 35 Ph.D. theses defended by postgraduate students and scientists. A.K. Valter was one of the founders of the Kharkiv school of experimental nuclear physics. In the co-authorship with I.I. Zalyubovs'kyi, he wrote the textbook "Nuclear Physics".

Illya Ivanovych Zalyubovs'kyi. Born in 1929 in Poltava region, died in 2013 in Kharkiv. Ukrainian scientist in nuclear physics.

The scientist was the first in the world who succeeded in solving the problem about the measurements of static electromagnetic moments of atomic nuclei. The cycle of his works ("Determination of the 


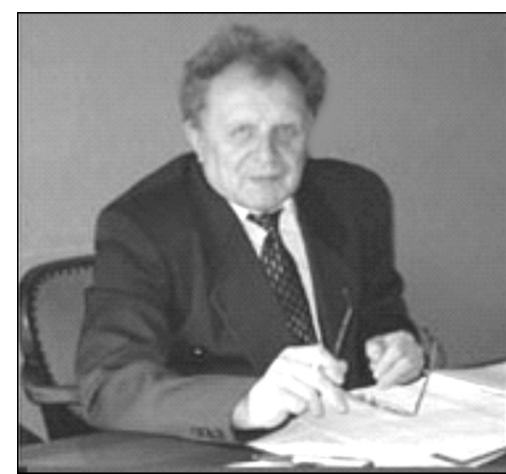

I.I. ZALYUBOVS'KYI

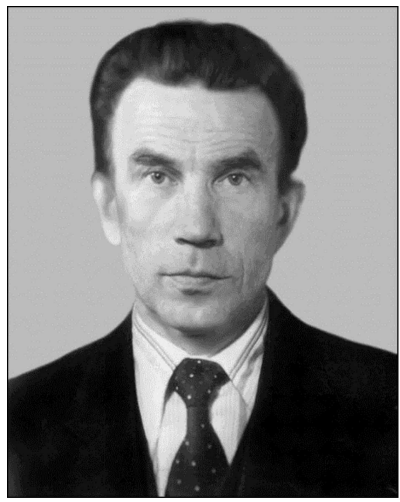

YE.D. VOLKOV

structure of atomic nuclei with the help of magnetic moments of aligned atoms") was awarded the K.D. Sinel'nikov Prize of the AS of the UkrSSR in 1983 and finds further development, when being applied to modern accelerators. I.I. Zalyubovs'kyi had considerable merit in the organization and further development of the Physico-Technical Faculty at the V.N. Karazin National University of Kharkiv [44].

In 1967, the employees of the chair headed by I.I. Zalyubovs'kyi discovered a phenomenon of radioemission by extensive air showers of cosmic rays. The corresponding cycle of works was awarded the State Prize of the UkrSSR in science and engineering (1971).

I.I. Zalyubovs'kyi created a powerful scientific school. Among his disciples, there are 8 Doctors of science and about $40 \mathrm{Ph}$.Ds. He is an author of the textbooks "Nuclear physics" (the State Prize of Ukraine in science and engineering, 1993), "Nuclear Spectroscopy", and two-volume "Nuclear Physics Handbook". His monograph "Introduction to Radia- tion Acoustics" was published in the USA, and his textbook "Nuclear Physics" is widely known in the UK, Bulgaria, Egypt, and China [45].

Yevgen Dmytrovych Volkov. Born in 1934 in the Nizhegorodskaya region (Russian Federation), died in 2012 in Kharkiv. Known physicist in plasma confinement and heating in toroidal magnetic traps, and in collective phenomena in plasma.

Ye. Volkov studied the heating of plasma and its confinement in stellarator systems, plasma properties, and plasma turbulence in order to explain anomalies of transport processes in magnetic traps. He developed programs for the experimental research of the process of high-temperature plasma confinement in toroidal magnetic traps of the stellarator type and the physical model of a thermonuclear reactor on the basis of stellarator systems [46].

Ye. Volkov headed a team created for the construction of the stellarator "Sirius" in Ukraine. This task was successfully fulfilled in record-breaking short terms, and the first experiments on the "Sirius" installation were started already at the beginning of 1964 [47]. A number of discoveries were made: the limiting gas-kinetic plasma pressure was measured, at which the equilibrium of plasma filament in the stellarator becomes broken; the drift instability of plasma was revealed and demonstrated to be responsible for abnormally high losses of particles and energy in plasma across the magnetic field; a conclusion was drawn about a necessity to change to currentless methods of plasma generation and heating in stellarators; and it was shown that the Bohm limit can be substantially exceeded in stellarators with respect to both the plasma lifetime and the energy time. Those results were included into the state register of inventions under the title " The phenomenon of turbulent heating and anomalous resistance of plasma" (1972, diploma N 112).

Ye. Volkov worked at the National Center of Science "Kharkiv Institute of Physics and Technology" of the NASU and at the V.N. Karazin National University of Kharkiv. He was a winner of the K.D. Sinel'nikov Prize of the AS of the UkrSSR (1985), the State Prize of Ukraine in science and engineering (2005) "For collective mechanisms of plasma heating and transfer in toroidal magnetic traps" (together with A.G. Zagorodny, V.I. Zasenko, K.M. Stepanov, V.V. Chechkin, O.M. Shvets, M.I. Nazarov, S.V. Kasilov, A.I. Skybenko, and 
V.S. Mykhailenko), and an author of about 400 publications.

In 2009, the scientists from the Kharkiv Institute of Physics and Technology managed to photograph an atom for the first time in the science history [48]. They aligned tens of carbon atoms in a vacuum chamber and passed an electric discharge through them. Radiation by the last atom in the chain was registered with the help of an electron microscope, which enabled the scientists to obtain an image of an electron cloud around the nucleus [49].

Georgii Antonovich Gamow. Born in 1904 in Odesa, died in 1968 in Boulder (USA). American physicist of the Ukrainian origin, Corresponding Member of the AS of the USSR (1932-1938), Member of the National Academy of Sciences of the USA (since 1953).

G. Gamow studied at the Odesa (1921-1922) and Petrograd (1922-1928) Universities. When training at the Göttingen University (Germany), he developed the quantum-mechanical theory of alpha decay (1928) and demonstrated that even low-energy particles can penetrate through a potential barrier [50]. On the basis of his theory, the scientist managed to estimate the nucleus size (of an order of $10^{-15} \mathrm{~m}$ ) and give a theoretical substantiation [51] to the empirical GeigerNuttall law (1911),

$\log T=A+\frac{B}{\sqrt{Q_{\alpha}}}$

where $T$ is the half-life period for $\alpha$-radioactive nuclei, $Q_{\alpha}$ the energy of an $\alpha$-particle, whereas $A$ and $B$ are constants that weakly depend on the atomic number of daughter nuclei, $Z$.

Later [52], the Geiger-Nuttall law was rewritten in the form

$\log T=\frac{9.54 Z^{0.6}}{\sqrt{Q_{\alpha}}}-51.37$,

where $T$ is reckoned in second units, and $Q_{\alpha}$ in megaelectronvolts.

G. Gamow is one of those who put forward the concept of "tunnel effect". He showed that the escape of an $\alpha$-particle is a result of its passage through a potential barrier and developed a model for the rectangular potential well (1928). The Gamow theory was quickly recognized in the scientific world.

G. Gamow formulated a concept of energy levels in the nucleus. He demonstrated that protons are the

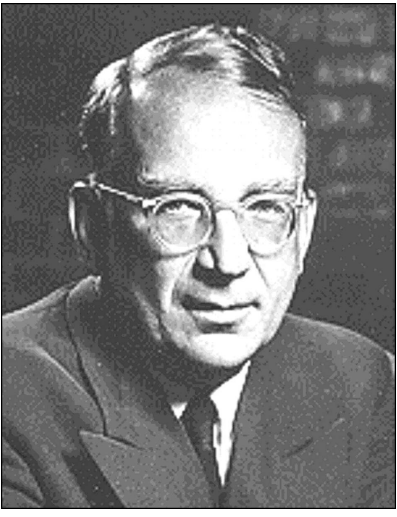

G.A. GAMOW

most effective "nuclear projectiles". Together with Edward Teller, he generalized the beta-decay theory (1936), formulated selection rules in the beta-decay theory, and introduced a concept known as GamowTeller transition.

In 1937-1940, G. Gamow developed the first consistent theory of evolution for stars regarded as thermonuclear energy sources. Together with E. Teller (1942), he proposed a theory of red giant star structure. In 1946-1948, G. Gamow developed a theory describing the formation of chemical elements by means of a consecutive neutrino capture and a model of "hot Universe". In the framework of the latter, he predicted the relict background radiation and estimated its temperature in $3 \mathrm{~K}$ [53] (according to modern data, $T=2.725 \mathrm{~K}$ ). The Gamow theory was experimentally confirmed in the course of the experimental discovery of the relict background (1965). In 1978, the American researchers A. Penzias and R. Wilson became Nobel Laureates in physics "for the discovery of cosmic microwave background radiation".

The scientific works by Gamow were devoted to quantum mechanics, atomic and nuclear physics, astrophysics, cosmology, and biology. The scientist was a known popular-science writer (he was awarded the Kalinga Prize by UNESCO for his work in popularizing science, 1956), and an author of many popularscience books.

Georges Charpak. Born in 1924 in Dąbrowica (Poland), died in 2010 in Paris (France). French physicist, who was born in Ukraine (today, the Rivne region), Nobel Laureate in physics (1992).

In 1954, G. Charpak obtained the doctoral degree in nuclear physics and, in 1959, started to work 


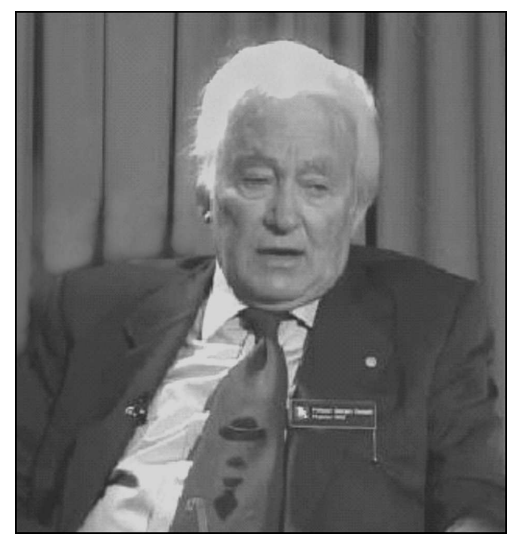

G. CHARPAK

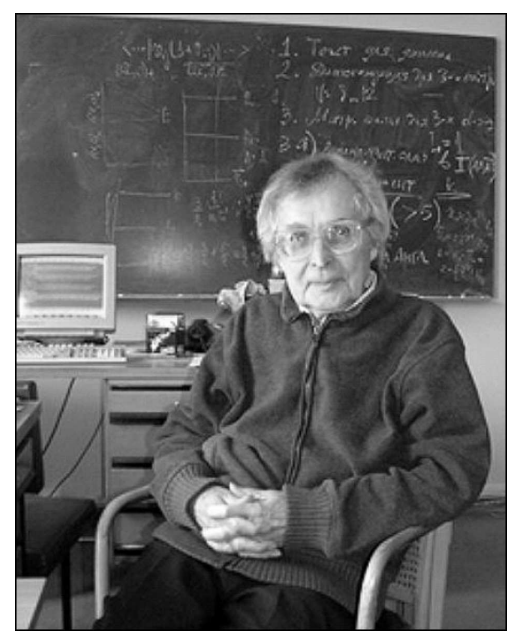

G.F. FILIPPOV

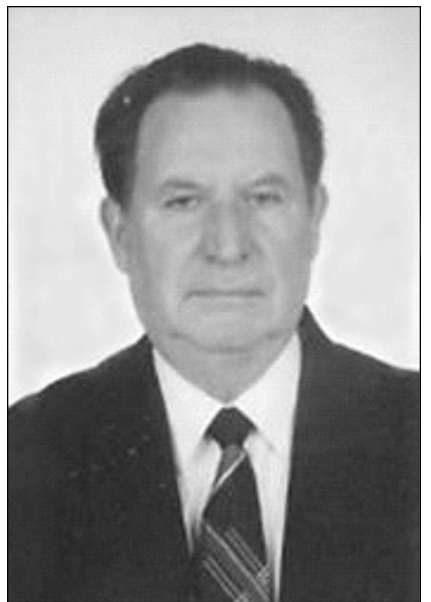

I.V. KHIMICH at the European Organization for Nuclear Research (CERN). In 1992, the scientist was awarded the Nobel Prize in physics "for the invention and development of particle detectors, in particular, the multiwire proportional chamber". Those counters were called "Charpak's chambers".

The scientist was an activist of the peaceful use of nuclear energy. In 1971, G. Charpak was awarded the Ricard Prize by the French Physical Society (this is a prize for encouraging physicians and those who promote the development of medicine) and the High Energy and Particle Physics Prize (1989). G. Charpak was a member of the Board of Sponsors of the journal "Bulletin of the Atomic Scientists".

After the Chernobyl disaster, G. Charpak's aspiration to help in diagnostics of irradiated people failed, because the Soviet Ukraine demonstratively refused. G. Charpak mentioned Ukraine in his interviews and memoirs [54]. In one of his interviews, the scientist noted: "If my way does not lead to Ukrainian lands, I call Ukraine to myself. And each time She comes: from my own heart" [55].

Gennadii Fedorovich Filippov. Born in 1932 in Moscow. Head of the Laboratory of the structure of atomic nuclei at the M.M. Bogolyubov Institute for Theoretical Physics of the NAS of Ukraine.

The scientist performed a cycle of works in the theory of collective excitations of atomic nuclei. The model of nonaxial nuclei, which was proposed by G.F. Filippov together with Academician A.S. Davydov won a wide international recognition and became known in science as the Davydov-Filippov model [56].

In 1981, G.F. Filippov and V.I. Ovcharenko were awarded the K.D. Sinel'nikov Prize of the NAS of Ukraine for their monograph "Microscopic Theory of Collective Excitations of Atomic Nuclei" [57].

Ivan Vasylyovych Khimich. Born in 1935 in the Zakarpattya region. Professor of the Chair of theoretical physics at the Uzhgorod National University.

The main scientific works of I.V. Khimich are devoted to fundamental directions in modern theoretical and nuclear physics: the relativistic axiomatic quantum field theory, the theory of elementary particle interactions, physics of high-energy particles, physics of nuclear isomeric states, the theory of pair nucleon correlations in nuclei, and the theory of superfluid states of atomic nuclei [58]. In 1986-1990, according to the government order, the employees of the Chair of nuclear physics under the supervision of I.V. Khimich 
carried out a research of the radiation resistance of elements and devices of electronic facilities in the framework of the program of space researches [59].

I.V. Khimich is the author and a coauthor of 150 scientific and methodological works. He has trained 4 Ph.Ds. Two of his disciples became Dr.Sci. in physics and mathematics.

Anatolii Glibovych Zagorodny. Born in 1951 in the village of Velyka Bagachka (the Poltava region). Dr.Sci. in physics and mathematics, Professor, Academician of the NAS of Ukraine (2006), VicePresident of the NAS of Ukraine, Director of the M.M. Bogolyubov Institute for Theoretical Physics of the NAS of Ukraine, the winner of the State Prize of Ukraine in science and engineering (2005).

A.G. Zagorodny is a known expert, in Ukraine and abroad, in theoretical and mathematical physics, physics of transport phenomena, and the plasma theory [60]. He (together with I.P. Yakymenko and Yu.L. Klimontovych) developed a statistical theory of spatially confined plasma-molecular systems and, on its basis, studied the influence of interaction between the plasma and molecular subsystems on electromagnetic fluctuations in such systems. A.G. Zagorodny also developed the theory of braking radiation in plasma-molecular systems, which consistently considers all probable scattering processes with the participation of charged particles and molecules, including their ionization and recombination, and the theory of electron and molecular scatterings at collective fluctuations. For a cycle of works on the statistical theory of plasma-molecular systems, A.G. Zagorodny together with his coauthors was awarded the K.D. Sinel'nikov Prize of the NAS of Ukraine. A.G. Zagorodny together with O.G. Sitenko generalized the theory of fluctuations in a stable stationary plasma to the case of turbulent plasma with fluid-like diffusion-drift motions. In his recent works, the scientist developed a consistent kinetic theory of dusty plasma.

A.G. Zagorodny is an author of more than 200 works, among which there is a known monograph "Statistical Theory of Plasma-Molecular Systems". His researches made it possible to estimate the influence of zone fluxes formed in the devices of controlled thermonuclear fusion on the diffusion coefficients under the saturated turbulence conditions.

The scientist is engaged into the pedagogical activity. He is the Professor of Taras Shevchenko National University of Kyiv, the Editor-in-Chief of the

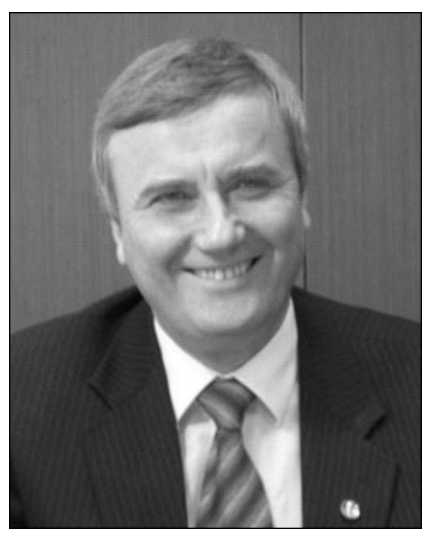

A.G. ZAGORODNY

"Ukrainian Journal of Physics", a member of the editorial boards of the "Bulletin of the NAS of Ukraine" and the international journal "Condensed Matter Physics".

\section{Conclusions}

Even having analyzed only a small number of works, we may draw conclusion about a considerable contribution of Ukrainian scientists to the formation of quantum physics. In particular, V. Mikhelson's researches dealing with the determination of Kirchhoff's function formed a basis for W. Wien's (Wien's law) and M.Planck's (the ultimate form of Kirchhoff's function) works. E. Kirillov is a discoverer of negative photoeffect; he studied this phenomenon and showed its relation with the process of formation of latent photographic image. O. Stasiw extended the Mott-Gurney scenario, which explained the process of formation of the latent photographic image (the Stasiw-Teltow model). V. Lashkaryov constructed a general theory describing the emergence of photoemf in semiconductors and discovered the bulk photoemf. With the help of his device (a prototype of the X-ray apparatus), I. Pulyui was the first in the world who obtained an X-ray image. The most probably that it was a "Pulyui lamp" that W. Röntgen used, when discovering X-radiation. Later, M. Pylchykov improved the "Pulyui lamp" by using a concave anticathode in it. L. Kordysh proposed a theory of continuous X-radiation spectrum and was close to the development of the complete theory of the anomalous Zeeman effect. O. Brods'kyi developed a general theory for isotope separation. D. Iwanenko is an author of the proton-neutron model of atomic nuclei. I. Za- 
lyubovs'kyi managed to solve a problem concerning the measurements of static electromagnetic moments of atomic nuclei. Ye. Volkov headed a group having built the stellarator "Sirius"first in Ukraine, where a number of world-level discoveries in plasma properties were made. G. Gamow developed a quantummechanical theory of alpha decay and, on its basis, managed to estimate the size of nucleus and give a theoretical substantiation of the empirical GeigerNuttall law; he formulated a concept of energy levels in the nucleus, showed that protons are the most effective "nuclear projectiles"; he is an author of the first consistent evolution theory for stars as thermonuclear energy sources; he developed the theory of chemical element formation through the consecutive neutrino capture; he created a model of "hot Universe" and, in its framework, predicted the existence of the relict background radiation. G. Charpak was awarded the Nobel Prize in physics "for the invention and development of particle detectors, in particular, the multiwire proportional chamber". With the help of Charpak's chamber, exact coordinates of particles can be determined, and its general principles are used in the work of the Large Hadron Collider. The scientists from the Kharkiv Institute of Physics and Technology managed to photograph an atom for the first time in the world...

The life of Ukrainian physicists went differently. Circumstances of N.D. Pilchikov's death (suicide or murder) remain obscure till now. Some outstanding scientists who lived in the Soviet Ukraine were unfairly condemned (V. Lashkaryov to 5 years, and D. Iwanenko to 3 years). Some others were forced to emigrate, but their souls always remained in Ukraine (O. Stasiw, G. Charpak). Many scientists are regarded to be Russian (V. Milhelson, D. Iwanenko), Soviet (G. Gamow, E. Kirillov), French (G. Charpak), rather than Ukrainian ones. However, all those physicists are united by the aspiration to create, contrary to all. To summarize, here are I. Pulyui's words: "There is no higher honor for an intelligent person than to protect his own and national honor and to work for his people's good to secure them a better fate without any reward".

1. R. Avgustyn. Physicists of Ukrainian Diaspora in the World Science (Aston, 2002) (in Ukrainian).

2. Axioms for Posterity: Ukrainian Names in the World Science. Edited by O.K. Romanchuk (Kamenyar, 1991) (in Ukrainian).
3. Axioms for Posterity: Ukrainian Names in the World Science. Edited by O.K. Romanchuk (Memorial, 1992) (in Ukrainian).

4. B.M. Andrianov. Essays in the History of Physics Development in Ukraine (VDPI, 1995) (in Ukrainian).

5. Elucidation of Ukrainian Physicists' Achievements in the Physics Course. Edited by I.R. Zachek, I.Ye Lopatyns'kyi, Y.Ya. Khrom'yak (DULP, 1999) (in Ukrainian).

6. M.V. Golovko. Application of Materials on the History of Domestic Science while Studying Physics and Astronomy ("International financial agency" Ltd., 1998) (in Ukrainian).

7. Yu. Ranyuk. Laboratory No. 1. Nuclear Physics in Ukraine (Akta, 2006) (in Ukrainian).

8. Yu.A. Khramov. History of Formation and Development of Physical Schools in Ukraine (Feniks, 1991) (in Russian).

9. V.A. Shenderovs'kyi. Let the Light of Science Not Die Away. Edited by E. Babchuk (Prostir Publ. House, 2009) (in Ukrainian).

10. M.V. Golovko. Domestic physics and astronomy in the last millennium. Fiz. Astronom. Shkoli 2, 49 (2001) (in Ukrainian).

11. A.G. Shepelev. 75 years of the discovery of type-II superconductivity (Shubnikov phase). Ukr. J. Phys. 56, 955 (2011).

12. V.G. Litovchenko. My scientific contacts with V.E. Lashkarev. Ukr. J. Phys. 59, 826 (2014).

13. M.V. Strikha. The centennial of semiconductor science: origins and Ukrainian contribution. Ukr. J. Phys. 59, 831 (2014).

14. V.A. Sokolov. To the history of blackbody radiation law (About V.A. Mikhelson's researches). Usp. Fiz. Nauk 43, 275 (1951) (in Russian).

15. D.I. Polishchuk. Kirillov Elpidifor Anempodystovych [http://fs.onu.edu.ua/clients/client11/web11/litopis/Kirilov.pdf] (in Ukrainian).

16. Encyclopedia of Modern Ukraine [http://esu.com.ua/ search_articles.php?id=6349] (in Ukrainian).

17. O. Dovhyj. The Stasiw-Teltow's model in classical photographic theory. Ukr. J. Phys. 47, 1099 (2002).

18. O. Stasiw, J. Teltow. Zur Photochemie der Silberhalogenide mit Fremdionenzusatzen. Ann. Physik. 432, 181 (1941) [DOI: 10.1002/andp.19414320303].

19. O. Stasiw, J. Teltow. Z. wiss. Photogr. 40, 157 (1941).

20. O. Stasiw, J. Teltow. Uber Fehlordnungserscheinungen in Silberhalogeniden mit Zusatzen. Ann. Physik. 1, 261 (1947) [DOI: 10.1002/andp.19474360413].

21. V.E. Lashkaryov Institute of Semiconductor Physics of the National Academy of Sciences of Ukraine [https:// isp.kiev.ua/images/Page_Image/History/50_years_institute/44.pdf].

22. V.P. Linnyk, V.E. Lashkaryov. Methods of X-ray focusing. Ukr. Fiz. Zap. 1, No. 1, 5 (1926) (in Ukrainian).

23. V.P. Linnyk, V.E. Lashkaryov. Determination of the refractive index for X-rays using the total reflection phenomenon. Ukr. Fiz. Zap. 1, No. 2, 3 (1927) (in Ukrainian).

ISSN 2071-0194. Ukr. J. Phys. 2017. Vol. 62, No. 1 
24. V.E. Lashkaryov. Appearance of photo-electromotive forces in semiconductors. Zh. Èksp. Teor. Fiz. 18, 917 (1948) (in Russian).

25. V.E. Lashkaryov Institute of Semiconductor Physics of the National Academy of Sciences of Ukraine [https:// isp.kiev.ua/images/Page_Image/History/50_years_institute/279.pdf].

26. In Memory of Anatolii Petrovych Gorban' (1938-2009). Ukr. J. Phys. 55, 356 (2010).

27. B. Lazaryuk. In the shadow of the own discovery aureola [http://gazeta.dt.ua/SCIENCE/u_tini_syayva_vlasnogo_vidkrittya.html] (in Ukrainian).

28. J. Puluj. Über die entstehung der Röntgen'schen Strahlen und ihre photographische Wirkung. Wiener Berichte 105, 228 (1896).

29. Site of physics teachers of Vinnytsya Technical Lyceum [http://vtl.vn.ua/fiziki/fizukr/f_u_pyl.html] (in Ukrainian).

30. N.D. Pilchikov. Radium and its rays. Vestn. Opytn. Fiz. Elem. Matem. 286, 217 (1900) (in Russian).

31. N.D. Pilchikov. Properties of radium rays. Vestn. Opytn. Fiz. Elem. Matem. 289, 3 (1900) (in Russian).

32. O.P. Maidebura. Перші радіобіологічні дослідження в Україні. Sumy Istor.-Arkhiv. Zh. 18-19, 67 (2012) (in Ukrainian).

33. Chair of Theoretical Physics of the Taras Shevchenko National University of Kyiv [http:// theory.phys.univ.kiev.ua/uk/content/kordysh-leon-yosypovych].

34. L.Ya. Shtrum. Leon Iosifovich Kordysh [Obituary]. Usp. Fiz. Nauk 13, 970 (1933) (in Russian).

35. O.A. Shcherbak. Development and interpretation of quantum concepts in Ukraine. Pytan. Istor. Nauky Tekhn. 1, 2 (2009) (in Ukrainian).

36. V.I. Vernadsky National Library of Ukraine [http:// www.nbuv.gov.ua/node/2263].

37. Ukrainians in the World [http://www.ukrainiansworld.org.ua/peoples/f9d3a671b01673e1/].

38. D. Iwanenko. The neutron hypothesis. Nature 129, 798 (1932).

39. G. Gamow, D. Iwanenko. Zur wellentheorie der materie. Z. Phys. 39, 865 (1926).

40. V. Ambarzumian, D. Iwanenko, Compt. Rend. Acad. Sci. 190, 582 (1930).

41. E. Gapon, D. Iwanenko. Zur Bestimmung der isotopenzahl. Die Naturwissenschaften 20, 792 (1932).

42. D. Iwanenko. Interaction of neutrons and protons. Nature 133, 981 (1934) [DOI: 10.1038/133981b0].

43. D. Iwanenko, A. Sokolow. On the mathematical formalism of the theory of showers. Phys. Rev. 53, 910 (1938) [DOI: 10.1103/PhysRev.53.910].

44. Chair of Nuclear and Medical Physics [http://wwwhtuni.univer.kharkov.ua/ftf/pht/kaf/keyaf.htm].

45. A. Tan'shina. Life devoted to science. Ilya Ivanovych Zalyubovs'kyi (15.06.1929-21.02.2013). Ukr. J. Phys. 58, 800 (2013).
46. Encyclopedia of Modern Ukraine [http://esu.com.ua/ search_articles.php?id=27660].

47. Yevgen Dmytrovych Volkov (03.03.1934-16.01.2012). Ukr. J. Phys. 57, 584 (2012).

48. I.M. Mikhailovskii, E.V. Sadanov, T.I. Mazilova, V.A. Ksenofontov, O.A. Velikodnaya. New possibilities of electron microscopy: ultra-high resolution and observation of atomic orbitals in carbon monoatomic chains. In Proceedings of the 9th International Conference on Physical Phenomena in Solids (Kharkiv, 2009) (in Russian).

49. Inside Science [https://www.insidescience.org/content/firstdetailed-photos-atoms/1184].

50. G. Gamow. Essay on the development of the theory of atomic nucleus structure. The theory of radioactive decay. Usp. Fiz. Nauk 10, 531 (1930) (in Russian).

51. G. Gamow. Zeit. f. Phys. 210, 51 (1928).

52. B.A. Brown. Simple relation for alpha decay half-lives. Phys. Rev. C 46, 811 (1992) [DOI: 10.1103/PhysRevC.46.811].

53. G. Gamow. Half an hour of creation... Phys. Today 3, No. 8, 16 (1950) [DOI: 10.1063/1.3066969].

54. G. Charpak. Mémoires d'un déraciné, physicien et citoyen du monde (Éditions Odile Jacob, 2008).

55. B. Odarchenko. Georges Charpak, a Nobel laureate from Polissta Dubrovytsya [http://www.radiosvoboda.org/content/article/24559081.html] (in Ukrainian).

56. Gennadii Fedorovich Filippov (to the 80th anniversary of his birthday). Ukr. J. Phys. 57, 684 (2012).

57. M.M. Bogolyubov Institute for Theoretical Physics [http://www.bitp.kiev.ua/san.htm].

58. The Higher School Academy of Sciences of Ukraine [http://anvsu.org.ua/index.files/Biographies/Khimich.htm].

59. To the 75-th anniversary of the Doctor of science in physics and mathematics, Professor of Uzhgorod National University Ivan Vasylyovych Khimich. Ukr. J. Phys. 55, 745 (2010).

60. The 60th anniversary of Academician of NASU A.G. Zagorodny. Visn. Nats. Akad. Nauk Ukr. 1, 59 (2011) (in Ukrainian).

Received 23.05.16.

Translated from Ukrainian by O.I. Voitenko

\section{I.В. Корсун}

\section{ВНЕСОК УКРАЇНСЬКИХ ВЧЕНИХ}

\section{У РОЗВИТОК КВАНТОВОЇ ФІЗИКИ}

$\mathrm{P}$ е $з$ ю м е

Проаналізовано внесок українських вчених у розвиток квантової фізики та проведено його класифікацію згідно 3 відповідними розділами. Доведено важливість даних досліджень у становленні цієї області фізики. Висвітлено пріоритетність низки робіт, які виконані українськими вченими, у світовій науці. Звернено увагу не лише на наукову діяльність фізиків, а й на їх педагогічну та просвітницьку роботу. Показано актуальність досліджень, які виконуються українськими вченими на даний час. 